\title{
Work facility design for VCO operator using integrated quality function deployment and Analytic Hierarchy Process
}

\author{
Sri Indrawati*, Abdullah 'Azzam, and Wini Wiliyanti \\ Industrial Engineering, Universitas Islam Indonesia, Yogyakarta, Indonesia
}

\begin{abstract}
The Musculoskeletal disorder (MSDs) is skeletal muscle disorders that lead to damage in nerves, muscles, joints and cartilages. The damage is caused by muscle tension and degeneration. From the preliminary research in virgin coconut oil (VCO) processing industry, Central Java, Indonesia, there are potential risk of MSDs for workers. The majority of operators complaining on the right thigh (score 37) and left thigh (score 35). In addition, 50\% of operators is work with moderate risk (rapid entire body assessment scores 4-7) and 50\% others at a high risk level (rapid entire body assessment scores 8-10). Therefore, improvement is needed to prevent MSDs through work facility design using an integrated quality function deployment (QFD) method. In QFD, there is a concept screening phase to select some product design concept. To determine the priority, the QFD method can be integrated with analytic hierarchy process (AHP) method. The research shows that attributes of work facility needed by user are ergonomic, portable, durable and aesthetic. Concept design B have the highest priority score 0,32 and selected as the final work facility design. The technical specification are made from mahogany wood with an attractive design, red colour combination and developed based on user's anthropometry data.
\end{abstract}

\section{Introduction}

The coconut oil processing industry is one small and medium size enterprise in Indonesia that have a good business development with abundant raw materials availability. The area of coconut plantations in Indonesia is the largest in the world of 3,88 million ha [1]. The coconut plantation owned by civilians of $96,6 \%$ and the remaining is state sectors $(0,7 \%)$ and private sectors $(2,7 \%)$. The average coconut fruit production is 15,9 billion pieces per year with a total of 3,75 million tons of water, 0,75 million tons of shell charcoal, 1,8 million tons of coir fibre and 3,3 million tons of coconut husk dust [2].

Based on preliminary research in virgin coconut oil (VCO) processing industry, Central Java, Indonesia, the work posture is at risk of causing musculoskeletal disorders as seen in Figure 1. The potential of musculoskeletal disorders is caused by over bending posture and sitting with static position in repetitive movement within eight hours.
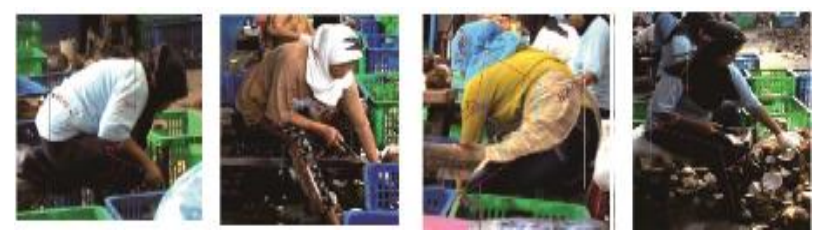

Figure 1. Working Postures of VCO Operators

Improving the work facility design in VCO processing industry is a way to reduce the risk of musculoskeletal disorders [3]. The work facility required by VCO processing workstation operators consist of temporary chairs and coconut storage box. There are several methods that can be used to design the work facility. Quality function deployment (QFD) is one of the many methods used by manufacturing companies for products based on consumer needs [4].

Many researchers have studied and documented the results of the QFD application. This method has been successfully used in developing food trolley products in India [5]. Based on that research, there are several consumer needs developed into the product, i.e. reusability, modular design, ergonomic and aesthetics. The method of QFD is also an integrated approach to modeling some product design criterias that are prioritized in work chair products for office environment [6]. QFD also sucessfully used for sailing boat material selection in India [7].

QFD can be used to design loser lift with a good quality [8]. The new product of mineral water that being improved using QFD have a significant potential product sucess [9]. This method is used to develop a concept design to fulfil the customer needs for multifunction scisor product [10]. QFD can also sucessfuly applied in a challenging environment of social housing and other service sectors through some model modifications [11]. The QFD is a powerful tool for deploying consumer needs to product design in steel manufacturing industry [12].

A new product strategy for direct open moulds product already develop to produce an innovative product through integration of QFD and theory of creative problem solving

\footnotetext{
Corresponding author: sriindrawati@uii.ac.id
} 
(TRIZ) [13]. In QFD, there is concept screening phase to select the design concept based on user needs and then developed into a prototype [14]. In that phase, an assessment of each design concept is done to create a product development priority. Analytic hierarchy process (AHP) is one method that can be integrated with QFD to prioritize the product design concept. This method has been widely implemented in various industries both manufacturing and services. Using AHP, the importance of each user's needs for the product can be clearly identified [15].

\section{Basic Theory}

\subsection{Quality Function Deployment (QFD)}

QFD is a product development method with a systematic process framework and focuses on consumer needs (voice of customer), improving the process to achieve maximum effectiveness [16]. There are three main phase for implementing QFD [17]:

a. Voice of customer identification that consists of determining attributes that consumers are interested in (in the form of qualitative data) and measuring the importance of each attributes.

b. Technical specifications determination that consist of several stages, i.e. identifying and measuring the importance of each technical specification to satisfy every customers needs attributes that obtained by the following equation (Annuraj et al, 2013):

$$
B_{j}=\sum_{i=1}^{n} K_{i j} H_{i}
$$

where, $\mathbf{J}$ is row vector for technical specification weight $(\mathrm{j}=1, \ldots, \mathrm{m}), \mathrm{Kij}$ is weight indicated by the relationship matrix $(i=1, \ldots, n, j=1, \ldots, m)$, Hi is column vector of consumer needs weight $(i=1, \ldots$, $\mathrm{n}), \mathrm{m}$ is number of technical specification and $\mathrm{n}$ is number of consumer spesification. Then the other stages are development direction and target value, develop the concept design and concept screening.

c. Analysis and interpretation to analyze the overall product development process that already done.

\subsection{Analytic Hierarchy Process (AHP)}

AHP is one of decision making process tool for a simple or complex problem. A decision priority is chosen based on several criterias decomposed from a problem [18]. So AHP helps to solve complex problems by compiling a hierarchy of criteria, subjectively assessed by expert or decision maker and then draw a consideration for developing weights or priorities for problem solution. There are several phase in AHP [19]:

a. Identify the problem.

b. Develop a problem hierarchical structure that consist of criteria and alternative solutions.

c. Perform a pairwise comparison matrix with numbers that represent the relative importance of an attribute to other attributes for prioritizing attributes and alternative problem solutions. Priority decisions can be calculated from priority weight of criteria (PW criteria) and priority weight of alternative solution (PW alternative) using this formulation:

$$
\mathrm{PK}=\sum \text { PW Criteria } x \text { PW Alternative }
$$

d. Compute eigenvalues and test the consistency. If the concistency value is more than $100 \%$, then the input data assessment should be corrected. However, if the consistency ratio is less than or equal to 0,1 , then the data can be used to support decicion making process [20].

\section{Research Framework}

Research on work facility design for VCO processing operators consists of three main stages, i.e. identification of user needs, determination of technical specifications, house of quality development, concept generation and concept screening. The research was conducted in VCO processing industry in Central Java, Indonesia. Identification of user needs is conducted through a survey to all operators at VCO processing workstation. This survey is used to determine the user needs and its priority. Only valid and reliable data that used in the work facility design and development. The importance level of user requirement attributes is obtained using AHP method. Furthermore, the technical specifications are determined to fulfill the user needs. After developing a list of technical specifications, a correlation analysis between technical specifications and user needs is done to prioritize technical specifications due to resource constraints to fulfil user's needs. Then concept generation is developed to bring the idea of work facility development. In this phase, concept design of work facility is determined in detail. In concept screening, all concept design alternatives performance is evaluated based on user needs using AHP method. The best concept design alternative then being developed into a VCO work facility prototype.

\section{Discussion}

There are four types of user needs as VCO work facility atttributes that must be developed. Ergonomic becomes highest priority requirement of 0,33 . Security and convenience in use are some needs required by users. That needs serves to reduce the potential risk of musculoskeletal disorders. The type of wood used must have a strong characteristic. While the dimensions of VCO work facility should base on the user's body anthropometry. The second attribute is portable with a priority score of 0,27 because the operators need a work facility that is easy to move. To realize that needs, the work facility should have a light weight so it can be moved by one person. Durable and aesthetic are the last factors that have the same priority score of 0,2 . User needs a durable work facility that easy to maintain and not easily damaged during use. Types of wood and a robust design can be used to fulfill that user needs. In addition, the 
physical appearance of VCO work facility required by the user are interesting and simple design. That characteristics can be influenced by several factors, i.e. design of chairs and temporary coconut shelter, type of wood and finishing process.

The technical specification that developed based on user needs contain some of variables as shown in Table 1. There are four user needs for VCO work facility design consisting of chair and coconut shelter box. Seven technical specification of VCO work facility design are determined to fulfil that needs.

Table 1. List of Technical Specification Metrics

\begin{tabular}{|c|c|l|c|c|c|c|}
\hline $\begin{array}{c}\text { No. } \\
\text { Metrics }\end{array}$ & $\begin{array}{c}\text { No. } \\
\text { Needs }\end{array}$ & Technical Specification & $\begin{array}{c}\text { Technical } \\
\text { Weight }\end{array}$ & Unit & $\begin{array}{c}\text { Direction of } \\
\text { Goodness }\end{array}$ & Value \\
\hline 1 & 3,4 & Shape of a chair & 1,2 & Subj & $\circ$ & Standard \\
\hline 2 & 1 & Size of product bearing & 1,65 & $\mathrm{Cm}$ & $\circ$ & $42 \times 32$ \\
\hline 3 & 3,4 & Wood type & 1,2 & List & $\uparrow$ & Standard \\
\hline 4 & 1,2 & Chair dimensions & 2,46 & $\mathrm{Cm}$ & $\uparrow$ & $57 \times 32 \times 80$ \\
\hline 5 & 1 & Box dimensions & 1,65 & $\mathrm{Cm}$ & $\uparrow$ & $60 \times 32 \times 100$ \\
\hline 6 & 2 & Total mass of products & 1,35 & $\mathrm{Kg}$ & $\downarrow$ & $<10$ \\
\hline 7 & 4 & Color & 1 & Subj & $\uparrow$ & Standard \\
\hline
\end{tabular}

Furthermore, the priority of technical specifications is determined as a basis of work facility development process. The technical specification with the highest priority score is the chair dimension at 2,46 . While the smallest priority score is color.

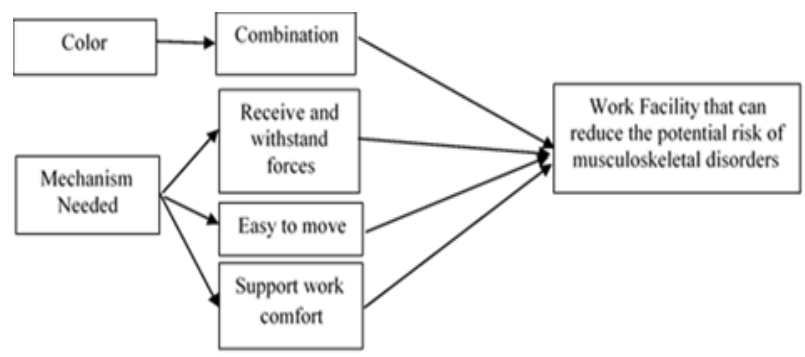

Figure 2. Problem decomposition diagram of VCO work facility design

The priority score indicates that the chair dimension has an important role in VCO work facility design to meet the user needs. Chair dimension have a strong positive correlation to the two technical specification of VCO work facility design, i.e. the temporary coconut storage box dimension and the total mass of product. The temporary coconut storage box dimension should be adjusted to chair dimension so that users feel comfortable during work. From the focus list of VCO work facility development, the product design problem can be decomposed as shown in Figure 2.

After identifying the problems of VCO work facility design, some feasible concept design alternatives are generated in a concept generation as shown in Table 2 . There are four design concept alternatives that being generated based on problem decomposition diagram, i.e. design concept $\mathrm{A}, \mathrm{B}, \mathrm{C}$ and $\mathrm{D}$. Each design concept alternatives are developed based on specification combination of wood type, color, box position and seat bearing.

Table 2. Concept Design of VCO Work Facility

\begin{tabular}{|c|c|l|}
\hline No. & Type of Concept & \multicolumn{1}{|c|}{ Specification } \\
\hline 1 & A & Teak dutch wood, bright colors, box position in front, with seat bearings \\
\hline 2 & B & Mahogany wood, bright colors, box position in front, with seat bearings \\
\hline 3 & C & Teak dutch wood, dark color, box position in side, no seat bearings \\
\hline 4 & D & Mahogany wood, dark color, box position in side, no seat bearings \\
\hline
\end{tabular}

Further a design concept screening is done to select the best concept design using AHP method. Based on the calculation of consistency ratio, all user answer to the work facility attributes that being asked have a value below 0,1 . So the data can be used for the next phase. The concept design $\mathrm{B}$ have a highest work facility performance. It is shown from the highest priority score of 0,32 compared with other concept design alternatives. It is indicated that concept design $\mathrm{B}$ becomes the first priority to be produced. The specification of concept design $\mathrm{B}$ is using mahogany wood with virtual prototype as shown in Figure 3.
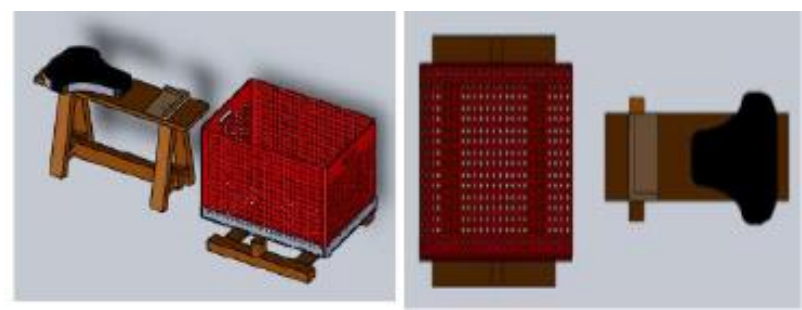

Figure 3. VCO work facility design

\section{Conclusion}

Based on the result of research that have been done for VCO work facility design by integrating QFD and AHP method, it can be concluded that the work facility attributes that needed by user are ergonomic, portable, durable and aesthetic. The alternative concept design that choosed based on the highest priority of development is the concept design $\mathrm{B}$. The priority score of concept design $\mathrm{B}$ is 0,32 . The final VCO work facility design is made with mahogany wood. This product also have an attractive design with a combination of red color and have dimension that matches to the user's body anthropometry.

Researchers thank to the support of Industrial Engineering Department, Faculty of Industrial Technology and Board of Planning Universitas Islam Indonesia.

\section{References}

1. Ministry of Industry, Roadmap Industri Pengolahan Kelapa, Directorate of Agricultural and Chemistry Department, Indonesia, (2009)

2. Board of Agricultural Research and Development, Prospek dan Arah Pengembangan Agribisnis Kelapa, Departemen Pertanian. Indonesia, (2009) 
3. Rostykus, W., Winnie, I., Mallon, J., Musculoskeletal Disorders: Five Common Management Approach, Professional Safety, Vol. December 2013: 35-42, (2013)

4. Kaebernick, H., Farmer, L.E, Mozar, S., Concurrent Product and Process Design, The University of New South Wales, USA, (1996)

5. Anuraj, N.P., Srinivasa, V. Ravichandran, Design of a Food Trolley for Hospital India, SASTECH Journal, Vol. 12: 90-98, (2013)

6. Mohanty, P.P. \& Mahaptra, S.S., Design Of Office Chair: A Quality Function Deployment Approach, Journal of Advanced Materials Manufacturing and Characterization, Vol 3.: 520-523, (2013)

7. Prasad, K. \& Chakraborty, S. A., Quality Function Deployment-Based Model for Materials Selection, Journal of Materials \& Designs, Vol. 49: 525-535, (2013)

8. Widodo, Y. \& Ikatrinasari, Z.F., Implementasi Quality Function Deployment Untuk Meningkatkan Kualitas Produk Lift, Jurnal Ilmiah Teknik Industri, Vo.2., No.3: 195-203, (2014)

9. Moldovan, L., QFD Employment for a New Product Design of a Mineral Water Company, Procedia Technology, Vol. 12: 462-468, (2014)

10. Mustakim. Integrasi Quality Function Deployment dan KANO Guna Perencanaan dan Pengembangan Produk Gunting Multifungsi. Widya Teknika, Vol. 23, No.1: 21-28, (2015)

11. Kassela, K., Papalexi, M., Bamford, D., Applying Quality Function Deployment to Social Housing, The TQM Journal, Vol. 29. Issue. 3 : 422-437, (2017)

12. Moody, A.K., Lal, R.R., Pandey, V., Analysis of Customer Oriented Product Development with Quality Function Deployment, International Journal of Mechanical Engineering and Technology, Vol. 8, Issue 5: 270-279, (2017)
13. Caligiana, G., Liverani, A., Francia, D., Frizziero, L., Donnici, G., Integrating QFD and TRIZ for Innovative Design, Journal of Advanced Mechanical Design, Systems and Manufacturing, Vol. 11., No. 2: 1-15, (2017)

14. Ikmar, S.B.S. \& Firdaus, M.B.I., Implementation of Quality Function Deployment (QFD) in Design AntiTheft Motorcycle Device, Journal of Mechanical Manufacturing, Vol. 1: 132-146, (2014)

15. Battistoni, E., Colladon, A.F., Scarabotti, L., Schiraldi, M.M., Analytical Hierarchy Process for New Product Development, International Journal of Engineering Business Management, Vol.5, No.42: 1$8,(2013)$

16. Walden, J., Performance Excellence: A QFD Approach, International Journal of Quality \& Reliability Management, Vol. 20, Issue 1: 123-133, (2003)

17. Cohen, L., Quality Function Deployment: How to Make QFD Work for You, Addison-Wesley, Michigan, (1995)

18. Saaty, T.L., The Analytic Hierarchy Process, University of Pittsburgh, Pittsburgh, (1988)

19. Mulyono, S., Teori Pengambilan Keputusan, Lembaga Penerbit Fakultas Ekonomi Universitas Indonesia, Jakarta, (1996)

20. Davoodi, A., On Inconsistency of a Pairwise Comparison Matrix, International Journal of Industrial Mathematics, Vol. 4: 343-350, (2009) 